\title{
The hallmarks of CMV-specific CD8 T-cell differentiation
}

\author{
Sara P. H. van den Berg ${ }^{1,2}$. Iris N. Pardieck ${ }^{3}$ (D) Josien Lanfermeijer ${ }^{1,2} \cdot$ Delphine Sauce $^{4} \cdot$ Paul Klenerman $^{5,6}$. \\ Debbie van Baarle ${ }^{1,2} \cdot$ Ramon Arens $^{3}$ (B)
}

Received: 12 March 2019 / Accepted: 2 April 2019 / Published online: 13 April 2019

(c) The Author(s) 2019

\begin{abstract}
Upon cytomegalovirus (CMV) infection, large T-cell responses are elicited that remain high or even increase over time, a phenomenon named memory T-cell inflation. Besides, the maintained robust T-cell response, CMV-specific T cells seem to have a distinctive phenotype, characterized by an advanced differentiation state. Here, we will review this "special" differentiation status by discussing the cellular phenotype based on the expression of CD45 isoforms, costimulatory, inhibitory and natural killer receptors, adhesion and lymphocyte homing molecules, transcription factors, cytokines and cytotoxic molecules. In addition, we focus on whether the differentiation state of CMV-specific CD8 T cells is unique in comparison with other chronic viruses and we will discuss the possible impact of factors such as antigen exposure and aging on the advanced differentiation status of CMV-specific CD8 T cells.
\end{abstract}

Keywords Cytomegalovirus $\cdot$ CD8 T cell $\cdot$ Differentiation $\cdot$ Phenotype

Edited by: Matthias J. Reddehase.

Sara P. H. van den Berg, Iris N. Pardieck, Debbie van Baarle and Ramon Arens contributed equally to the work.

This article is part of the Special Issue on Immunological Imprinting during Chronic Viral infection.

Ramon Arens

R.Arens@lumc.nl

1 Center for Infectious Disease Control, National Institute for Public Health and the Environment, Bilthoven, The Netherlands

2 Laboratory of Translational Immunology, Department of Immunology, University Medical Center Utrecht, Utrecht University, Utrecht, The Netherlands

3 Department of Immunohematology and Blood Transfusion, Leiden University Medical Center, Albinusdreef 2, 2333 ZA Leiden, The Netherlands

4 Sorbonne Université, INSERM, Centre d'Immunologie et des Maladies Infectieuses (CIMI-Paris), Paris, France

5 Nuffield Department of Medicine, Peter Medawar Building for Pathogen Research, University of Oxford, Oxford, UK

6 NIHR Biomedical Research Centre, John Radcliffe Hospital, Oxford, UK

\section{Introduction}

Human cytomegalovirus (HCMV), a beta-herpesvirus family member, infects around $60 \%$ of the worldwide population [1]. In healthy individuals, HCMV establishes a persistent latent infection with episodes of reactivation. Although HCMV infection is usually asymptomatic, in immunocompromised (e.g., HCMV-seronegative recipients receiving organs of HCMV-positive donors) and immune immature individuals (neonates), HCMV can cause serious disease [2].

A remarkable feature of HCMV infection is the capacity to elicit large T-cell responses that do not follow the typical contraction pattern after primary infection. Instead, the percentages of $\mathrm{CMV}$-specific $\mathrm{T}$ cells remain high or even increase over time [3], a phenomenon named memory T-cell inflation [4, 5]. In the Western world, frequencies around $10 \%$ of HCMV-specific T cells of the total memory T-cell pool are commonly observed (with outliers $>50 \%$ ), and this is found in both healthy and immunocompromised individuals $[6,7]$. In elderly, the frequency of circulating HCMVspecific $\mathrm{T}$ cells is higher than in younger adults, and the reactivity of these cells can be restricted to a limited number of epitopes [8-11]. The increase in frequency of HCMVspecific CD8 T cells with age is also observed in studies with immunocompromised individuals and is similar to frequencies found in healthy donors [12]. 
Besides the sustained large T-cell response, the phenotype of CMV-specific $\mathrm{T}$ cells seems to be characteristic as well, typified by an advanced differentiation state. Here, we discuss the particulars of this "special" differentiation phenotype and asked the question whether the differentiation state of CMV-specific CD8 T cells is unique. In addition, we discuss the potential impact of antigen exposure and aging on the differentiation status of CMV-specific CD8 T cells.

\section{The differentiation phenotype of CMV-specific CD8 T cells}

\section{CD45 isoforms}

Isoforms of the protein tyrosine phosphatase CD45 are expressed at various levels on hematopoietic cell lineages. The high-molecular-weight isoform CD45RA is expressed by naïve $\mathrm{T}$ cells, while the low molecular weight isoform CD45RO is expressed on activated and memory $\mathrm{T}$ cells and is implicated in increasing the sensitivity of TCR signalling [13]. Advanced differentiation of T cells is, however, characterized by a lack of CD45RO while CD45RA is reexpressed. A large proportion of the HCMV-specific T cells have the latter phenotype (in combination with downregulation of costimulatory molecules, this phenotype is also called TEMRA), and this seems quite unique for HCMV [14]. For example, Epstein-Barr virus (EBV)-specific CD8 T cells are predominantly CD45RO positive [15] and human immunodeficiency virus (HIV)-specific T cells express lower levels of CD45RA [16].

\section{Costimulatory and inhibitory receptors}

The advanced differentiation state of CMV-specific T cells is also marked by the lack of expression of the costimulatory receptors CD27 and CD28, which are otherwise constitutively expressed on naïve $T$ cells [17]. This is in contrast to other virus-specific CD8 T cells. For example, EBV and hepatitis $\mathrm{C}$ virus (HCV)-specific $\mathrm{T}$ cells more often display expression of CD27 and CD28, and HIV-specific CD8 T cells, despite advanced loss of CD28, still express CD27 [17], although this may also depend on the disease state [18].

Acute HCMV infections frequently occur in CMV-negative transplant recipients receiving a CMV-positive organ. In these individuals, the CMV-specific T-cell response consists of mainly $\mathrm{CD} 27^{+} \mathrm{CD} 28^{-} \mathrm{CD} 45 \mathrm{RA}^{-} \mathrm{CD} 45 \mathrm{RO}^{+}$memory T cells shortly after the peak of CMV infection [19]. In time, expression of CD27 is lost and CD45RA is re-expressed on the majority of the cells $[20,21]$. The gradual loss of CD27 is also observed in mouse models, and is likely caused by chronic antigenic triggering [22].
In mouse models, the functional role of CD27 and CD28 has been studied in CMV infection and indicated that CD28 costimulation is especially important during primary infection to enhance CMV-specific T-cell expansion while CD27 and its ligand CD70 seem to play an activating role during both the primary and latent phase of infection [22-26]. The costimulatory receptor OX40 is transiently upregulated upon activation, and is important during the latent phase [27].

Programmed cell death 1 (PD-1), cytotoxic T-lymphocyte antigen 4 (CTLA-4), T-cell immunoglobulin domain and mucin domain protein 3 (TIM-3), lymphocyte activation gene 3 (LAG-3) and CD160 are inhibitory receptors associated with the exhaustion phenotype of T cells [28]. PD-1 was identified to be abundant on chronic lymphocytic choriomeningitis virus (LCMV)-specific T cells in mice models [29] and was next shown to be upregulated on T cells in a number of chronic viral infections including HIV [30, 31], hepatitis B virus (HBV) [32] or HCV [33]. In addition, PD-1 and other inhibitory molecules are abundantly found on $\mathrm{T}$ cells in the tumor microenvironment and this aspect forms the basis for reinforcing exhausted $\mathrm{T}$ cells by blocking these inhibitory molecules [34]. Indeed, as demonstrated by variants of LCMV eliciting either acute or chronic infection, the induction of the exhausted phenotype is caused by strong chronic antigenic triggering [35], and is elevated by the lack of CD4 T-cell help [29, 36].

Interestingly, during the latent phase, circulating CMVspecific $\mathrm{T}$ cells express relatively low levels of inhibitory receptors [37, 38]. PD-1 expression on CMV-specific T cells is lower compared to chronic virus-specific $\mathrm{T}$ cells against HBV [32], HIV [30, 38-40] and EBV-specific T cells [37, 38]. Likewise, also TIM-3, CD160 and 2B4 are expressed at lower levels in CMV-specific T cells compared to HIVspecific T cells [40]. Nonetheless, the inter-individual variation of PD-1 and 2B4 expression observed for CMV-specific $\mathrm{T}$ cells can be substantial $[33,40]$. This heterogeneity of PD-1 expression could reflect different differentiation phenotypes of virus-specific memory T cells [38], and this may be independent of their capacity to control viruses. Indeed, PD-1 expression is not associated with functional capacity (e.g., secretion of cytokines and degranulation). In addition, data showed that CD8 T cells can further up-regulate PD-1 when they are activated [38]. Altogether this suggests that PD-1, expressed on CMV-specific T cells, is independent of T-cell exhaustion.

\section{Natural killer receptors}

Although originally reported as natural killer cell receptors (NKRs), a number of these receptors such as immunoglobulin-like receptors (KIRs, LIRs such as CD85j) and lectinlike receptors (CD94/NKG2, KLRG1) are also expressed on CD8 T cells [41]. These molecules are likely implicated in 
the fine-tuning of the anti-viral response. Indeed, primary CMV infection induces an increased expression of both inhibitory and activating NKRs, which remains high during the latent infection phase, while viral load is undetectable [42]. Yet, the precise role of different NKRs remains to be determined.

Similarity between CMV-specific $\mathrm{T}$ cells and other chronic viruses is found in the expression patterns for several inhibiting NKRs. CMV-specific T cells, just like EBV and HIV-specific T cells, show substantial expression of CD85j (ILT2/LIR-1) compared to the overall T-cell pool [43-45]. This CD85j expression is most abundant in TEMRAs and CD28- CD8 T cells [44], suggesting an advanced differentiation phenotype. In addition, the overwhelming majority of CMV, EBV and HIV-specific T cells express KLRG1, often together with loss of expression of CD28 and CCR7, indicating that these cells have undergone multiple cell divisions but are still active in cytokine production [46, 47]. Also, expression of NKG2A is increased on CMV-specific CD8 T cells $[42,48]$. However, KIRs do not seem upregulated on CMV-specific T cells and/or HIV-specific T cells: only small fractions express CD158 variants or NKB-1 (KIR3DL1) [43, 49]. Although increased expression of NKG2C on CD8 T cells is associated with CMV-seropositivity [42] and CMVreactive $\mathrm{T}$ cells upon restimulation show NKG2C expression [44], CMV-specific T cells stained with MHC class I tetramers do not seem to express NKG2C [42, 50]. Overall, CD8 $\mathrm{T}$ cells specific for CMV show low expression of KIRs and NKG2C and increased expression of CD85j, NKG2A and KLRG1 during the latent phase of the infection.

CMV-specific CD8 T cells also express the NKRs CD56 and $\mathrm{CD} 57 . \mathrm{CD}^{2} 6^{+} \mathrm{CD} 8 \mathrm{~T}$ cells are known for their natural killer-like cytotoxicity [51], and CD56 is shown on CMVspecific $\mathrm{T}$ cells in renal transplant patients [52] and healthy individuals (unpublished observations, S. van den Berg and D. van Baarle). CD57 expression represents a cellular phenotype associated with poor proliferative capacity but high cytotoxic potential [53]. On CMV-specific T cells, CD57 expression, often co-expressed with CD85j, increases with age, but a large variation in expression exists [44, 54]. CD57 expression on CMV, EBV, and HIV-specific CD8 T cells was low to moderate in adults $[32,46]$, whereas others reported overall a high expression on these virus-specific $\mathrm{T}$ cells of CD57 in older subjects [55]. In the latter, CMV-specific T cells seem to express CD57 at higher levels than EBV and HIV-specific T cells, albeit not substantially.

\section{Adhesion molecules and lymphocyte homing}

CMV-specific CD8 $\mathrm{T}$ cells are largely negative for CCR7 and CD62L [16, 17, 49], which are homing receptors for lymphoid organs. This property, which is shared with $\mathrm{T}$ cells specific for other chronic viruses, allows the cells to circulate throughout the body, and reside in peripheral tissue, spleen and blood.

CX3CR1, which recognizes fractalkine expressed by endothelial cells, is abundantly expressed by CMV-specific cells $[10,56]$ during the primary and latent infection, whereas CCR1 and CXCR6 are only present during the acute phase [37]. High and intermediate expression of CX3CR1 seems to be unique for CMV-specific CD8 T cells in both human and mice $[37,56]$, as the frequency of this chemokine receptor on EBV [57], HBV and HCVspecific T cells is much lower [58]. CMV-specific CD8 T cells with intermediate expression of CX3CR 1 associate with self-renewal potential, but the role of CX3CR1 seems to be redundant, since memory T-cell inflation is unaltered in case of CX3CR1 deficiency [56]. In addition, CXCR3 is commonly expressed on CMV-specific T cells as well as EBV-specific T cells [57]. The homing cell adhesion molecule CD44 is uniformly high expressed on all CMV-specific T cells $[48,59]$.

\section{Transcription factors, cytokines and cytotoxic molecules}

Transcription factors (TFs) are crucial regulators of cellular differentiation and function including the cytotoxic potential and cytokine secretion. For CD8 T cells, the TFs Eomes and T-bet are particularly useful to determine the functional profile. For example, T-bet ${ }^{\mathrm{dim}}$ and Eomes ${ }^{\text {high }}$ expression profiles are associated with expression of exhaustion markers as observed in HIV-specific T cells, whereas many CMV and EBV-specific $\mathrm{T}$ cells exhibit intermediate levels of Eomes and high levels of T-bet [37, 40, 60]. Blimp-1 and the Homolog of Blimp-1 in T cells (Hobit) are also clearly expressed by CMV-specific CD8 T cells [61, 62].

Related to the above-described TF profile is the high granzyme $\mathrm{B}$ and perforin expression in CMV-specific CD8 T cells $[39,40,49,63]$. These cells also abundantly produce IFN- $\gamma$ and TNF after re-stimulation, while IL-2 is produced by only a subset of the inflationary CMV-specific CD8 T cells [63]. The expression of the above-described effector molecules is consistent with the functional non-exhaustion phenotype of CMV-specific T cells, and underlines their functional status and requirement for lifelong protection against viral dissemination [64]. Analysis of transcriptional networks in inflating cells reveals a module of genes strongly driven by T-bet, not seen in T-cell exhaustion [65].

The low IL-2 production may coincide with the reduced expression of IL-2R $\beta$ (CD122/IL-15R $\beta$ ) on CMV-specific CD8 $T$ cells $[37,48,63,66]$. In addition, virus-specific effector CD8 $\mathrm{T}$ cells activated in vivo during primary EBV or CMV infection down-regulate IL-7R $\alpha$ (CD127) and IL-15R $\alpha$ (CD215) expression [67]. With time, CMV-specific CD8 T cells maintain high levels of IL- $15 \mathrm{R} \alpha$. This contrasts 


\section{The advanced differentiated CMV-specific CD8 T cell}



Fig. 1 The advanced differentiation phenotype of CMV-specific CD8 $T$ cells. The advanced differentiated CMV-specific CD8 T cells are typified by either expression or down-modulation of different surface receptors, cytokines and transcription factors. Surface receptors that are expressed are depicted in blue on the left side of the cell, whereas down-modulated or non-expressed surface receptors are depicted in gray on the right side of the cell. CMV-specific CD8 $\mathrm{T}$ cells express the CD45 isoform CD45RA, different natural killer receptors (CD85j, CD56, CD57, NKG2A and KLRG1), IL-15R $\alpha$ and the homing receptors CX3CR1 and CD44. These cells do not

with the lower expression of IL7R $\alpha$ on CMV-specific CD8 T cells compared to EBV-specific CD8 T cells [32, 68-70]. Interestingly, IL-7R $\alpha$ expression was tightly associated with population size in blood [70]. However, this correlation was not sustained in tonsillar lymphoid tissue where CMV-specific $\mathrm{T}$ cells were less abundant than EBV-specific T cells, despite higher IL-7R $\alpha$ expression [70]. express or lowly express CD45RO, costimulatory receptors CD27 and $\mathrm{CD} 28$, natural killer receptors (KIRs and $\mathrm{NKG} 2 \mathrm{C}$ ), inhibitory receptors (PD-1, TIM-3, CD160 and 2B4), homing receptors (CXCR6, CCR1, CD62L and CCR7) and cytokine receptors IL-2R $\beta$ (CD122) and IL-7R $\alpha$ (CD127). CMV-specific CD8 T cells have intermediate expression of the transcription factor Eomes and strong expression of transcription factors Hobit, Blimp-1 and T-bet. Related to this transcription profile is the high expression of cytokines IFN- $\gamma$ and TNF- $\gamma$ and the cytotoxic molecules granzyme $\mathrm{B}(\mathrm{GrB})$ and perforin. In general, IL-2 production by CMV-specific CD8 T cells is low

\section{Is the advanced differentiated T-cell phenotype unique?}

The above-described advanced differentiated CD8 T-cell phenotype is clearly observed for CMV-specific T cells, and could be considered as a distinct type of effector-memory (EM) T cells. The phenotype involves expression of inhibitory molecules such as KLRG1, CD57 and CD56, yet the cells are nevertheless functional with respect to cytokine production and cytotoxicity (Fig. 1). However, the advanced 
differentiated phenotype is not entirely exclusive as also other viruses can elicit CD8 T cells with a similar differentiation status. Less attention is given to this since either only a small subset among the total memory pool has this phenotype (e.g., upon infection with EBV or HIV) or the frequencies of the late-stage differentiated CD8 T cells are generally lower compared to those in CMV infection (e.g., infection with herpes simplex virus-1 (HSV-1) [71] and parvoviruses B19 and PARV4 [72]. One clear feature is that high doses of adenovirus-based vaccine vectors can actually induce a comparable phenotype (and transcriptome) to CMV [56], which is also accompanied with a high frequency of the cells, which makes this a vaccine platform with great potential. As variation exists in the differentiation state of CMV-specific T cells between individuals, we will next discuss factors that influence the T-cell differentiation.

\section{Establishment of the advanced differentiation phenotype}

The phenotype of the CMV-specific CD8 T cells is strongly connected with the magnitude of the CMV-specific T-cell response. Cross-sectional human studies show that in both healthy and immunosuppressed individuals, a high HCMVspecific T-cell response is associated with a high percentage of advanced differentiated $T$ cells within the total specific T-cell population [44, 73-75]. Nevertheless, the association between the differentiation state and level of CMV-specific $\mathrm{T}$ cells is shown in experimental mouse models [74, 76]. Low-dose inoculums elicit fewer circulating CMV-specific CD8 T cells, and these cells have a less advanced differentiation phenotype. Accordingly, interference with an established mouse CMV infection by antiviral treatment reduces the frequency of the CMV-specific CD8 T-cell response, and also in this setting, the CD8 $\mathrm{T}$ cells acquired a lesser differentiated phenotype compared to CMV-infected mice that are untreated [77].

Differences in the infectious dose of primary CMV infection may be instrumental in causing the large variation of the advanced-stage differentiation status of CMV-specific $\mathrm{T}$ cells that exists between individuals. CMV-specific CD8 $\mathrm{T}$ cells may reach an advanced differentiation phenotype already early after infection, and then maintain this status stably over time. In young individuals and even in children, advanced differentiated CMV-specific T cells can appear [78-80]. Thus, the (primary) infectious dose might determine the viral setpoint (the initial balance between virus and host after primary infection) [81] and thereby subsequently influence the level and amount of viral reactivation episodes and consequent antigen triggering of CMV-specific T cells.
Notably, within the inflationary epitope-specific memory $\mathrm{T}$-cell population, not all CMV-specific $\mathrm{T}$ cells acquire the late-stage differentiation phenotype. Depending on the viral dose, a significant portion can attain a central-memory (CM) phenotype [76]. These CM-like CD8 T cells produce more IL-2 and are probably dominantly contributing to T-cell expansion upon re-challenge [82]. Also, within the total pool of CMV-specific T cells non-inflationary $\mathrm{T}$ cells exist directed against a distinct subset of epitopes, which never acquire the EM-like differentiation during the latent phase of infection [63]. In line with this are the observations that the enhanced differentiation state of the HCMV-specific T cell is observed for different epitopes [32]. A critical aspect for virus-specific $\mathrm{T}$ cells undergoing memory inflation or not, does not depend on the intrinsic property of the peptide epitope but on the context of viral gene expression. CMV epitopes that normally induce non-inflationary CD8 T-cell responses from its native site can induce an inflationary response due to $\mathrm{C}$-terminal localization allowing better peptide processing, also leading to a more advanced differentiated phenotype [83, 84].

Besides the infectious dose, aging also impacts the differentiation status of the CMV-reactive T cells. In crosssectional studies, it was observed that the number of HCMVspecific T cells increases over time [6, 47]. And this is accompanied by an increase of HCMV-specific cells that re-express CD45RA [11] and express KLRG1 [47]. Moreover, using new computational tools, it was recently shown that inflationary MCMV-specific T cells are progressively differentiating in time (based on the markers KLRG1, CD44, CD27 and CD62L), long after the initial infection $[74,85]$. In line with these studies is the observation that telomeres of HCMV-specific CD8 T cells are significantly shorter compared to the corresponding phenotypic subsets of the total CD8 T-cell pool [86]. The shortest telomere lengths were found in old individuals compared to young individuals in all different memory subsets (based on CD27 and CD45RA distinction). Overall, this indicates that with aging CMVspecific cells undergo more proliferation and enhanced differentiation.

Important for the enhanced differentiation after CMV infection is the capacity of CMV to become latent. Essentially, latent genomes can sporadically desilence at certain genetic loci, which lead to gene expression of antigenic peptide-encoding genes without entering the productive cycle $[87,88]$. This allows intermittent re-exposure of antigen to the virus-specific T cells, which keeps these cells "tickled" during a lifetime, but avoids continuous strong antigenic stimulation leading eventually to exhaustion as is the case for chronic infections with HIV or certain LCMV strains [89]. The large and gradual expansion of CMV-specific CD8 $\mathrm{T}$ cells with an enhanced differentiation phenotype could be interpreted as a lack of complete control of the virus. The 
T cells that show enhanced differentiation, thus, attempt to retain control over full reactivation of the virus. Accordingly, interference with an established MCMV infection by antiviral treatment reduces the frequency of the CMV-specific CD8 T-cell response, and also in this setting, the CD8 T cells reverted to a lesser differentiated phenotype compared to CMV-infected mice that were untreated [77]. It is generally assumed that the immune evasion strategies of CMV targeting the innate and adaptive immunity are critical for the long-term persistence of the virus [90,91], but whether some of these strategies are capable of specifically modulating particular phenotypic characteristics of the CMVspecific $\mathrm{T}$ cell is unknown. The need and purpose of the maintenance of high-frequency CMV-specific CD8 T cells that progressively differentiate are, thus, unclear and may be driven by an ongoing shift in the virus-host equilibrium.

Another important aspect might be the broad tropism of CMV and its systemic spread as localized CMV infection results in less inflation and less advanced differentiation [92, 93]. The distinctive tropism of CMV, including the wide variety of target cells, innate immune cells such as myeloid cells as CMV vehicles, and the infrequent expression of immediate early genes leading to abortive reactivation, may thus, co-determine the fate of the T-cell response, and such characteristics may be the key differences compared to other chronic viruses that frequently reactivate, like EBV. Finally, the size of the genome of CMV is relatively large (compared to most other viruses), which may contribute to elicit larger T-cell responses and to the likelihood to encompass epitopes inducing inflationary T-cell responses.

\section{Concluding remarks}

The characteristics of CMV-specific T cells, i.e., maintenance of high numbers and the late-differentiated EM-like phenotype, have been a subject of interest. Although the CMV-specific memory T-cell populations are diverse (in magnitude and phenotype) between individuals, it is evident that a large proportion of these cells are advanced differentiated. This particular phenotype seems to be related to the nature of CMV infection because it is more abundantly found upon CMV infection compared to other chronic viruses. The $\mathrm{CMV}$-specific $\mathrm{T}$ cells are often late-stage differentiated $\mathrm{T}$ cells, have shorter telomeres and express inhibitory molecules such as KLRG1, CD57 and CD85j, yet the cells are nevertheless functional with respect to cytokine production and cytotoxicity [94]. Further studies are needed to unravel this seemingly conflicting feature of CMV-specific $\mathrm{T}$ cells. Large prospective studies in humans could provide further insight, but such studies may still be complicated given the possible impact of MHC heterogeneity in the human population compared to inbred mice [95]. Notably, the data discussed here reflect mainly the differentiation of the circulating CMV-specific $\mathrm{T}$ cells, which represents a subgroup of the total CD8 T-cell pool in the body. Whether a late-differentiated phenotype "uniquely" related to CMV infection is also present in the tissue-resident memory T-cell population remains to be elucidated. Several papers reveal a dual impact of CMV infection and aging on immune subsets [96-100]. Prevalence of CMV infection increases with age $[101,102]$, suggesting that CMV may take advantage over a senescent immune system. How long-term infection of CMV is able to change the virus-host balance leading to gradual higher levels of advanced differentiated T cells is unknown. Due to aging, immune control may gradually wane leading to more frequent reactivation.

Acknowledgements This research was funded by a grant from NWOTTW (Project 15380, awarded to RA), NIHR SF (PK) and Wellcome Trust (WT106695MA to PK).

\section{Compliance with ethical standards}

Conflict of interest The authors declare that they have no conflict of interest.

Open Access This article is distributed under the terms of the Creative Commons Attribution 4.0 International License (http://creativeco mmons.org/licenses/by/4.0/), which permits unrestricted use, distribution, and reproduction in any medium, provided you give appropriate credit to the original author(s) and the source, provide a link to the Creative Commons license, and indicate if changes were made.

\section{References}

1. Cannon MJ, Schmid DS, Hyde TB (2010) Review of cytomegalovirus seroprevalence and demographic characteristics associated with infection. Rev Med Virol 20(4):202-213

2. Sissons JG, Wills MR (2015) How understanding immunology contributes to managing CMV disease in immunosuppressed patients: now and in future. Med Microbiol Immunol 204(3):307-316

3. Holtappels R, Pahl-Seibert MF, Thomas D, Reddehase MJ (2000) Enrichment of immediate-early 1 (m123/pp89) peptide-specific CD8 T cells in a pulmonary CD62L(lo) memory-effector cell pool during latent murine cytomegalovirus infection of the lungs. J Virol 74(24):11495-11503

4. Karrer U, Sierro S, Wagner M, Oxenius A, Hengel H, Koszinowski UH et al (2003) Memory inflation: continuous accumulation of antiviral $\mathrm{CD}^{+} \mathrm{T}$ cells over time. J Immunol 170(4):2022-2029

5. O'Hara GA, Welten SP, Klenerman P, Arens R (2012) Memory $\mathrm{T}$ cell inflation: understanding cause and effect. Trends Immunol 33(2):84-90

6. Khan N, Hislop A, Gudgeon N, Cobbold M, Khanna R, Nayak L et al (2004) Herpesvirus-specific CD8 T cell immunity in old age: cytomegalovirus impairs the response to a coresident EBV infection. J Immunol 173(12):7481-7489 
7. Sylwester AW, Mitchell BL, Edgar JB, Taormina C, Pelte C, Ruchti $\mathrm{F}$ et al (2005) Broadly targeted human cytomegalovirusspecific $\mathrm{CD}^{+}{ }^{+}$and $\mathrm{CD} 8^{+} \mathrm{T}$ cells dominate the memory compartments of exposed subjects. J Exp Med 202(5):673-685

8. Komatsu H, Sierro S, Cuero V, Klenerman P (2003) Population analysis of antiviral T cell responses using MHC class I-peptide tetramers. Clin Exp Immunol 134(1):9-12

9. Vescovini R, Biasini C, Fagnoni FF, Telera AR, Zanlari L, Pedrazzoni M et al (2007) Massive load of functional effector $\mathrm{CD}^{+}$and $\mathrm{CD}^{+}{ }^{+} \mathrm{T}$ cells against cytomegalovirus in very old subjects. J Immunol 179(6):4283-4291

10. Remmerswaal EB, Havenith SH, Idu MM, van Leeuwen EM, van Donselaar KA, ten Berge IJ et al (2012) Human virus-specific effector-type T cells accumulate in blood but not in lymph nodes. Blood 119(7):1702-1712

11. Griffiths SJ, Riddell NE, Masters J, Libri V, Henson SM, Wertheimer A et al (2013) Age-associated increase of lowavidity cytomegalovirus-specific $\mathrm{CD} 8^{+} \mathrm{T}$ cells that re-express CD45RA. J Immunol 190(11):5363-5372

12. Engstrand M, Lidehall AK, Totterman TH, Herrman B, Eriksson BM, Korsgren O (2003) Cellular responses to cytomegalovirus in immunosuppressed patients: circulating $\mathrm{CD} 8^{+} \mathrm{T}$ cells recognizing CMVpp65 are present but display functional impairment. Clin Exp Immunol 132(1):96-104

13. Leitenberg D, Boutin Y, Lu DD, Bottomly K (1999) Biochemical association of CD45 with the $\mathrm{T}$ cell receptor complex: regulation by CD45 isoform and during $\mathrm{T}$ cell activation. Immunity 10(6):701-711

14. Derhovanessian E, Maier AB, Hahnel K, Beck R, de Craen AJ, Slagboom EP et al (2011) Infection with cytomegalovirus but not herpes simplex virus induces the accumulation of late-differentiated $\mathrm{CD}^{+}{ }^{+}$and $\mathrm{CD} 8^{+}$T-cells in humans. J Gen Virol 92(Pt 12):2746-2756

15. Kuijpers TW, Vossen MT, Gent MR, Davin JC, Roos MT, Wertheim-van Dillen PM et al (2003) Frequencies of circulating cytolytic, CD45RA ${ }^{+} \mathrm{CD} 27^{-}, \mathrm{CD}^{+} \mathrm{T}$ lymphocytes depend on infection with CMV. J Immunol 170(8):4342-4348

16. Chen G, Shankar P, Lange C, Valdez H, Skolnik PR, Wu L et al (2001) CD8 T cells specific for human immunodeficiency virus, Epstein-Barr virus, and cytomegalovirus lack molecules for homing to lymphoid sites of infection. Blood 98(1):156-164

17. Appay V, Dunbar PR, Callan M, Klenerman P, Gillespie GM, Papagno L et al (2002) Memory CD8 ${ }^{+} \mathrm{T}$ cells vary in differentiation phenotype in different persistent virus infections. Nat Med 8(4):379-385

18. van Baarle D, Kostense S, van Oers MH, Hamann D, Miedema F (2002) Failing immune control as a result of impaired $\mathrm{CD}^{+}$ T-cell maturation: CD27 might provide a clue. Trends Immunol 23(12):586-591

19. Wills MR, Okecha G, Weekes MP, Gandhi MK, Sissons PJ, Carmichael AJ (2002) Identification of naive or antigen-experienced human CD8(+) T cells by expression of costimulation and chemokine receptors: analysis of the human cytomegalovirusspecific CD8(+) T cell response. J Immunol 168(11):5455-5464

20. van Leeuwen EM, Koning JJ, Remmerswaal EB, van Baarle D, van Lier RA, ten Berge IJ (2006) Differential usage of cellular niches by cytomegalovirus versus EBV- and influenza virusspecific CD8 ${ }^{+}$T cells. J Immunol 177(8):4998-5005

21. Pipeling MR, West EE, Osborne CM, Whitlock AB, Dropulic LK, Willett MH et al (2008) Differential CMV-specific CD8 ${ }^{+}$ effector $\mathrm{T}$ cell responses in the lung allograft predominate over the blood during human primary infection. J Immunol 181(1):546-556

22. Welten SP, Redeker A, Franken KL, Benedict CA, Yagita H, Wensveen FM et al (2013) CD27-CD70 costimulation controls
$\mathrm{T}$ cell immunity during acute and persistent cytomegalovirus infection. J Virol 87(12):6851-6865

23. Arens R, Loewendorf A, Her MJ, Schneider-Ohrum K, Shellam GR, Janssen E et al (2011) B7-mediated costimulation of CD4 T cells constrains cytomegalovirus persistence. J Virol 85(1):390-396

24. Arens R, Loewendorf A, Redeker A, Sierro S, Boon L, Klenerman $P$ et al (2011) Differential B7-CD28 costimulatory requirements for stable and inflationary mouse cytomegalovirus-specific memory CD8 T cell populations. J Immunol 186(7):3874-3881

25. Welten SP, Melief CJ, Arens R (2013) The distinct role of $\mathrm{T}$ cell costimulation in antiviral immunity. Curr Opin Virol 3(4):475-482

26. Welten SP, Redeker A, Franken KL, Oduro JD, Ossendorp F, Cicin-Sain L et al (2015) The viral context instructs the redundancy of costimulatory pathways in driving CD8(+) T cell expansion. eLife 4:e07486

27. Humphreys IR, Loewendorf A, De TC, Schneider K, Benedict CA, Munks MW et al (2007) OX40 costimulation promotes persistence of cytomegalovirus-specific CD8 T cells: a CD4dependent mechanism. J Immunol 179(4):2195-2202

28. Blackburn SD, Shin H, Haining WN, Zou T, Workman CJ, Polley A et al (2009) Coregulation of $\mathrm{CD}^{+} \mathrm{T}$ cell exhaustion by multiple inhibitory receptors during chronic viral infection. Nat Immunol 10(1):29-37

29. Barber DL, Wherry EJ, Masopust D, Zhu B, Allison JP, Sharpe $\mathrm{AH}$ et al (2006) Restoring function in exhausted CD8 T cells during chronic viral infection. Nature 439(7077):682-687

30. Trautmann L, Janbazian L, Chomont N, Said EA, Gimmig S, Bessette B et al (2006) Upregulation of PD-1 expression on $\mathrm{HIV}$-specific $\mathrm{CD}^{+} \mathrm{T}$ cells leads to reversible immune dysfunction. Nat Med 12(10):1198-1202

31. Day CL, Kaufmann DE, Kiepiela P, Brown JA, Moodley ES, Reddy $S$ et al (2006) PD-1 expression on HIV-specific T cells is associated with T-cell exhaustion and disease progression. Nature 443(7109):350-354

32. He XH, Jia QT, Li FY, Saltis M, Liu Y, Xu LH et al (2008) CD8(+) T cells specific for both persistent and non-persistent viruses display distinct differentiation phenotypes but have similar level of PD-1 expression in healthy Chinese individuals. Clin Immunol 126(2):222-234

33. Owusu Sekyere S, Suneetha PV, Kraft AR, Zhang S, Dietz J, Sarrazin C et al (2015) A heterogeneous hierarchy of coregulatory receptors regulates exhaustion of HCV-specific CD8 T cells in patients with chronic hepatitis C. J Hepatol 62(1):31-40

34. Topalian SL, Drake CG, Pardoll DM (2015) Immune checkpoint blockade: a common denominator approach to cancer therapy. Cancer Cell 27(4):450-461

35. Shin H, Blackburn SD, Blattman JN, Wherry EJ (2007) Viral antigen and extensive division maintain virus-specific CD8 T cells during chronic infection. J Exp Med 204(4):941-949

36. Matloubian M, Concepcion RJ, Ahmed R (1994) CD4 ${ }^{+} \mathrm{T}$ cells are required to sustain $\mathrm{CD} 8^{+}$cytotoxic $\mathrm{T}$-cell responses during chronic viral infection. J Virol 68(12):8056-8063

37. Hertoghs KM, Moerland PD, van Stijn A, Remmerswaal EB, Yong SL, van de Berg PJ et al (2010) Molecular profiling of cytomegalovirus-induced human $\mathrm{CD}^{+} \mathrm{T}$ cell differentiation. J Clin Investig 120(11):4077-4090

38. Sauce D, Almeida JR, Larsen M, Haro L, Autran B, Freeman GJ et al (2007) PD-1 expression on human CD8 T cells depends on both state of differentiation and activation status. Aids 21(15):2005-2013

39. Petrovas C, Casazza JP, Brenchley JM, Price DA, Gostick E, Adams WC et al (2006) PD-1 is a regulator of 
virus-specific $\mathrm{CD}^{+}{ }^{+} \mathrm{T}$ cell survival in HIV infection. J Exp Med 203(10):2281-2292

40. Buggert M, Tauriainen J, Yamamoto T, Frederiksen J, Ivarsson MA, Michaelsson J et al (2014) T-bet and Eomes are differentially linked to the exhausted phenotype of $\mathrm{CD}^{+} \mathrm{T}$ cells in HIV infection. PLoS Pathog 10(7):e1004251

41. Huard B, Karlsson L (2000) KIR expression on self-reactive $\mathrm{CD}^{+} \mathrm{T}$ cells is controlled by T-cell receptor engagement. Nature 403(6767):325-328

42. van Stijn A, Rowshani AT, Yong SL, Baas F, Roosnek E, ten Berge IJ et al (2008) Human cytomegalovirus infection induces a rapid and sustained change in the expression of NK cell receptors on $\mathrm{CD}^{+} \mathrm{T}$ cells. J Immunol 180(7):4550-4560

43. Anfossi N, Doisne JM, Peyrat MA, Ugolini S, Bonnaud O, Bossy $\mathrm{D}$ et al (2004) Coordinated expression of Ig-like inhibitory MHC class I receptors and acquisition of cytotoxic function in human $\mathrm{CD}^{+} \mathrm{T}$ cells. J Immunol 173(12):7223-7229

44. Gustafson CE, Qi Q, Hutter-Saunders J, Gupta S, Jadhav R, Newell E et al (2017) Immune checkpoint function of CD85j in CD8 $\mathrm{T}$ cell differentiation and aging. Front Immunol 8:692

45. Ince MN, Harnisch B, Xu Z, Lee SK, Lange C, Moretta L et al (2004) Increased expression of the natural killer cell inhibitory receptor CD85j/ILT2 on antigen-specific effector CD8 $\mathrm{T}$ cells and its impact on CD8 T-cell function. Immunology 112(4):531-542

46. Ibegbu CC, Xu YX, Harris W, Maggio D, Miller JD, Kourtis AP (2005) Expression of killer cell lectin-like receptor G1 on antigen-specific human $\mathrm{CD} 8^{+} \mathrm{T}$ lymphocytes during active, latent, and resolved infection and its relation with CD57. J Immunol 174(10):6088-6094

47. Ouyang Q, Wagner WM, Voehringer D, Wikby A, Klatt T, Walter $\mathrm{S}$ et al (2003) Age-associated accumulation of CMV-specific $\mathrm{CD}^{+} \mathrm{T}$ cells expressing the inhibitory killer cell lectin-like receptor G1 (KLRG1). Exp Gerontol 38(8):911-920

48. Snyder CM, Cho KS, Bonnett EL, van Dommelen S, Shellam GR, Hill AB (2008) Memory inflation during chronic viral infection is maintained by continuous production of short-lived, functional T cells. Immunity 29(4):650-659

49. Gamadia LE, Rentenaar RJ, Baars PA, Remmerswaal EB, Surachno S, Weel JF et al (2001) Differentiation of cytomegalovirus-specific CD8(+) T cells in healthy and immunosuppressed virus carriers. Blood 98(3):754-761

50. Guma M, Angulo A, Vilches C, Gomez-Lozano N, Malats N, Lopez-Botet M (2004) Imprint of human cytomegalovirus infection on the NK cell receptor repertoire. Blood 104(12):3664-3671

51. Pievani A, Borleri G, Pende D, Moretta L, Rambaldi A, Golay J et al (2011) Dual-functional capability of $\mathrm{CD} 3^{+} \mathrm{CD} 56^{+} \mathrm{CIK}$ cells, a T-cell subset that acquires NK function and retains TCR-mediated specific cytotoxicity. Blood 118(12):3301-3310

52. Almehmadi M, Hammad A, Heyworth S, Moberly J, Middleton D, Hopkins MJ et al (2015) CD56 ${ }^{+} \mathrm{T}$ cells are increased in kidney transplant patients following cytomegalovirus infection. Transpl Infect Dis 17(4):518-526

53. Kared H, Martelli S, Ng TP, Pender SL, Larbi A (2016) CD57 in human natural killer cells and T-lymphocytes. Cancer Immunol Immunother 65(4):441-452

54. Northfield J, Lucas M, Jones H, Young NT, Klenerman P (2005) Does memory improve with age? CD85j (ILT-2/LIR-1) expression on CD8 T cells correlates with 'memory inflation' in human cytomegalovirus infection. Immunol Cell Biol 83(2):182-188

55. Hoji A, Connolly NC, Buchanan WG, Rinaldo CR Jr (2007) CD27 and CD57 expression reveals atypical differentiation of human immunodeficiency virus type 1 -specific memory CD8 ${ }^{+}$ T cells. Clin Vaccine Immunol 14(1):74-80
56. Gordon CL, Lee LN, Swadling L, Hutchings C, Zinser M, Highton AJ et al (2018) Induction and maintenance of CX3CR1intermediate peripheral memory CD8(+) $\mathrm{T}$ cells by persistent viruses and vaccines. Cell Rep 23(3):768-782

57. van de Berg PJ, Yong SL, Remmerswaal EB, van Lier RA, ten Berge IJ (2012) Cytomegalovirus-induced effector T cells cause endothelial cell damage. Clin Vaccine Immunol 19(5):772-779

58. Bottcher JP, Beyer M, Meissner F, Abdullah Z, Sander J, Hochst $\mathrm{B}$ et al (2015) Functional classification of memory CD8(+) $\mathrm{T}$ cells by CX3CR1 expression. Nat Commun 6:8306

59. Lang KS, Moris A, Gouttefangeas C, Walter S, Teichgraber V, Miller M et al (2002) High frequency of human cytomegalovirus (HCMV)-specific $\mathrm{CD}^{+} \mathrm{T}$ cells detected in a healthy $\mathrm{CMV}$ seropositive donor. Cell Mol Life Sci 59(6):1076-1080

60. van Aalderen MC, Remmerswaal EB, Verstegen NJ, Hombrink $\mathrm{P}$, ten Brinke A, Pircher $\mathrm{H}$ et al (2015) Infection history determines the differentiation state of human $\mathrm{CD}^{+} \mathrm{T}$ cells. J Virol 89(9):5110-5123

61. Vieira Braga FA, Hertoghs KM, Kragten NA, Doody GM, Barnes NA, Remmerswaal EB et al (2015) Blimp-1 homolog Hobit identifies effector-type lymphocytes in humans. Eur $\mathbf{J}$ Immunol 45(10):2945-2958

62. Kragten NAM, Behr FM, Vieira Braga FA, Remmerswaal EBM, Wesselink TH, Oja AE et al (2018) Blimp-1 induces and Hobit maintains the cytotoxic mediator granzyme B in CD8 T cells. Eur J Immunol 48(10):1644-1662

63. Munks MW, Cho KS, Pinto AK, Sierro S, Klenerman P, Hill AB (2006) Four distinct patterns of memory CD8 T cell responses to chronic murine cytomegalovirus infection. J Immunol 177(1):450-458

64. Jackson SE, Mason GM, Okecha G, Sissons JG, Wills MR (2014) Diverse specificities, phenotypes, and antiviral activities of cytomegalovirus-specific CD8 ${ }^{+}$T cells. J Virol 88(18):10894-10908

65. Marchi E, Lee LN, Klenerman P (2019) Inflation vs. exhaustion of antiviral $\mathrm{CD} 8^{+} \mathrm{T}$-cell populations in persistent infections: two sides of the same coin? Front Immunol 10:197

66. Sierro S, Rothkopf R, Klenerman P (2005) Evolution of diverse antiviral $\mathrm{CD} 8^{+} \mathrm{T}$ cell populations after murine cytomegalovirus infection. Eur J Immunol 35(4):1113-1123

67. Sauce D, Larsen M, Curnow SJ, Leese AM, Moss PA, Hislop $\mathrm{AD}$ et al (2006) EBV-associated mononucleosis leads to longterm global deficit in T-cell responsiveness to IL-15. Blood 108(1):11-18

68. van Leeuwen EM, de Bree GJ, Remmerswaal EB, Yong SL, Tesselaar K, ten Berge IJ et al (2005) IL-7 receptor alpha chain expression distinguishes functional subsets of virus-specific human $\mathrm{CD}^{+}$T cells. Blood 106(6):2091-2098

69. Boutboul F, Puthier D, Appay V, Pelle O, Ait-Mohand H, Combadiere B et al (2005) Modulation of interleukin-7 receptor expression characterizes differentiation of CD8 T cells specific for HIV, EBV and CMV. Aids 19(17):1981-1986

70. Sauce D, Larsen M, Leese AM, Millar D, Khan N, Hislop AD et al (2007) IL-7R alpha versus CCR7 and CD45 as markers of virus-specific $\mathrm{CD} 8^{+} \mathrm{T}$ cell differentiation: contrasting pictures in blood and tonsillar lymphoid tissue. J Infect Dis 195(2):268-278

71. Lang A, Brien JD, Nikolich-Zugich J (2009) Inflation and longterm maintenance of CD8 T cells responding to a latent herpesvirus depend upon establishment of latency and presence of viral antigens. J Immunol 183(12):8077-8087

72. Isa A, Kasprowicz V, Norbeck O, Loughry A, Jeffery K, Broliden $\mathrm{K}$ et al (2005) Prolonged activation of virus-specific $\mathrm{CD} 8^{+} \mathrm{T}$ cells after acute B19 infection. PLoS Med 2(12):e343

73. Gamadia LE, van Leeuwen EM, Remmerswaal EB, Yong SL, Surachno S, Wertheim-van Dillen PM et al (2004) The size and phenotype of virus-specific $\mathrm{T}$ cell populations is determined by 
repetitive antigenic stimulation and environmental cytokines. $\mathrm{J}$ Immunol 172(10):6107-6114

74. Redeker A, Remmerswaal EBM, van der Gracht ETI, Welten SPM, Hollt T, Koning F et al (2017) The contribution of cytomegalovirus infection to immune senescence is set by the infectious dose. Front Immunol 8:1953

75. Northfield J, Lucas M, Jones H, Young NT, Klenerman P (2005) Does memory improve with age? CD85j (ILT-2/LIR-1) expression on CD8 T cells correlates with 'memory inflation' in human cytomegalovirus infection. Immunol Cell Biol 83(2):182-188

76. Redeker A, Welten SP, Arens R (2014) Viral inoculum dose impacts memory $\mathrm{T}$-cell inflation. Eur J Immunol 44(4):1046-1057

77. Beswick M, Pachnio A, Lauder SN, Sweet C, Moss PA (2013) Antiviral therapy can reverse the development of immune senescence in elderly mice with latent cytomegalovirus infection. $\mathbf{J}$ Virol 87(2):779-789

78. van den Heuvel D, Jansen MA, Dik WA, Bouallouch-Charif H, Zhao D, van Kester KA et al (2016) Cytomegalovirus- and Epstein-Barr virus-induced T-cell expansions in young children do not impair naive $\mathrm{T}$-cell populations or vaccination responses: the generation R study. J Infect Dis 213(2):233-242

79. Gibson L, Piccinini G, Lilleri D, Revello MG, Wang Z, Markel S et al (2004) Human cytomegalovirus proteins pp65 and immediate early protein 1 are common targets for $\mathrm{CD}^{+} \mathrm{T}$ cell responses in children with congenital or postnatal human cytomegalovirus infection. J Immunol 172(4):2256-2264

80. Komatsu H, Inui A, Sogo T, Fujisawa T, Nagasaka H, Nonoyama $S$ et al (2006) Large scale analysis of pediatric antiviral $\mathrm{CD}^{+} \mathrm{T}$ cell populations reveals sustained, functional and mature responses. Immun Ageing 3:11

81. Reddehase MJ, Balthesen M, Rapp M, Jonjic S, Pavic I, Koszinowski UH (1994) The conditions of primary infection define the load of latent viral genome in organs and the risk of recurrent cytomegalovirus disease. J Exp Med 179(1):185-193

82. Redeker A, Welten SP, Baert MR, Vloemans SA, Tiemessen MM, Staal FJ et al (2015) The quantity of autocrine IL-2 governs the expansion potential of $\mathrm{CD}^{+} \mathrm{T}$ cells. J Immunol 195(10):4792-4801

83. Dekhtiarenko I, Jarvis MA, Ruzsics Z, Cicin-Sain L (2013) The context of gene expression defines the immunodominance hierarchy of cytomegalovirus antigens. J Immunol 190(7):3399-3409

84. Dekhtiarenko I, Ratts RB, Blatnik R, Lee LN, Fischer S, Borkner L et al (2016) Peptide processing is critical for T-cell memory inflation and may be optimized to improve immune protection by CMV-based vaccine vectors. PLoS Pathog 12(12):e1006072

85. Pardieck IN, Beyrend G, Redeker A, Arens R (2018) Cytomegalovirus infection and progressive differentiation of effectormemory T cells. F1000Research 7(F1000 Faculty Rev):1554

86. Riddell NE, Griffiths SJ, Rivino L, King DC, Teo GH, Henson SM et al (2015) Multifunctional cytomegalovirus (CMV)specific CD8(+) T cells are not restricted by telomere-related senescence in young or old adults. Immunology 144(4):549-560

87. Simon CO, Holtappels R, Tervo HM, Bohm V, Daubner T, Oehrlein-Karpi SA et al (2006) CD8 T cells control cytomegalovirus latency by epitope-specific sensing of transcriptional reactivation. J Virol 80(21):10436-10456

88. Seckert CK, Griessl M, Buttner JK, Scheller S, Simon CO, Kropp KA et al (2012) Viral latency drives 'memory inflation': a unifying hypothesis linking two hallmarks of cytomegalovirus infection. Med Microbiol Immunol 201(4):551-566
89. Cicin-Sain L, Arens R (2018) Exhaustion and inflation at antipodes of $\mathrm{T}$ cell responses to chronic virus infection. Trends Microbiol 26(6):498-509

90. Mocarski ES Jr (2002) Immunomodulation by cytomegaloviruses: manipulative strategies beyond evasion. Trends Microbiol 10(7):332-339

91. Jackson SE, Redeker A, Arens R, van Baarle D, van den Berg SPH, Benedict CA et al (2017) CMV immune evasion and manipulation of the immune system with aging. GeroScience 39(3):273-291

92. Beyranvand Nejad E, Ratts RB, Panagioti E, Meyer C, Oduro JD, Cicin-Sain L et al (2019) Demarcated thresholds of tumorspecific CD8 T cells elicited by MCMV-based vaccine vectors provide robust correlates of protection. J Immunother Cancer $7(1): 25$

93. Oduro JD, Redeker A, Lemmermann NA, Ebermann L, Marandu TF, Dekhtiarenko I et al (2015) Murine cytomegalovirus infection via the intranasal route offers a robust model of immunity upon mucosal CMV infection. J Gen Virol 97(1):185-195

94. Wallace DL, Masters JE, De Lara CM, Henson SM, Worth A, Zhang Y et al (2011) Human cytomegalovirus-specific CD8(+) $\mathrm{T}$-cell expansions contain long-lived cells that retain functional capacity in both young and elderly subjects. Immunology 132(1):27-38

95. Mansfield SA, Dwivedi V, Elgharably H, Griessl M, Zimmerman PD, Limaye AP et al (2019) Cytomegalovirus immunoglobulin G titers do not predict reactivation risk in immunocompetent hosts. J Med Virol 91(5):836-844

96. Roux A, Mourin G, Larsen M, Fastenackels S, Urrutia A, Gorochov $\mathrm{G}$ et al (2013) Differential impact of age and cytomegalovirus infection on the gammadelta T cell compartment. J Immunol 191(3):1300-1306

97. Souquette A, Frere J, Smithey M, Sauce D, Thomas PG (2017) A constant companion: immune recognition and response to cytomegalovirus with aging and implications for immune fitness. GeroScience 39(3):293-303

98. Bayard C, Lepetitcorps H, Roux A, Larsen M, Fastenackels S, Salle V et al (2016) Coordinated expansion of both memory $T$ cells and NK cells in response to CMV infection in humans. Eur J Immunol 46(5):1168-1179

99. Sauce D, Larsen M, Fastenackels S, Duperrier A, Keller M, Grubeck-Loebenstein B et al (2009) Evidence of premature immune aging in patients thymectomized during early childhood. J Clin Investig 119(10):3070-3078

100. Lopez-Sejas N, Campos C, Hassouneh F, Sanchez-Correa B, Tarazona R, Pera A et al (2016) Effect of CMV and aging on the differential expression of CD300a, CD161, T-bet, and eomes on NK cell subsets. Front Immunol 7:476

101. Pawelec G, McElhaney JE, Aiello AE, Derhovanessian E (2012) The impact of CMV infection on survival in older humans. Curr Opin Immunol 24(4):507-511

102. Bate SL, Dollard SC, Cannon MJ (2010) Cytomegalovirus seroprevalence in the United States: the national health and nutrition examination surveys, 1988-2004. Clin Infect Dis 50(11):1439-1447

Publisher's Note Springer Nature remains neutral with regard to jurisdictional claims in published maps and institutional affiliations. 